\title{
The Gulf of Mexico oil disaster: some legal issues
}

\author{
by C Chatterjee and Anna Lefcovitch
}

\section{INTRODUCTION}

The recent BP oil spill in the Gulf of Mexico which adversely affected the shore of Florida has provoked an outburst of accusations of corporate irresponsibility, particularly in the US, and one should appreciate the reasons for it. It has not only caused environmental damage but also cost the livelihood of numerous local firms and families, in addition to depleting or harming many resources of the Gulf of Mexico.

Whether the perpetrators of the damage, harm and suffering to human and animal lives were caused by BP directly or by their agent, from a legal standpoint BP cannot avoid liability under the principle of vicarious liability. The extent to which BP directly contributed to the disaster will be revealed in due course. BP has already paid a large sum of money to the locals (US\$256 m) in the form of compensation for damage caused to those who suffered from the catastrophic disaster, and it agreed to another US\$ 60 million in August. By agreeing to pay compensation BP has admitted its liability, even though no contractual arrangement existed between BP and those who suffered from this disaster. So what is the basis for this compensation, and did BP agree to pay it on the grounds of the breach of corporate responsibility, or the principle of corporate social responsibility, or both?

The aim of this article is to identify and briefly examine the legal issues that arose out of this incident. The reader's attention is drawn to the fact that despite the authors' best efforts much data was not made available to them; hence in many cases assumptions are used which seek to make a best guess in the circumstances.

\section{THE SCENARIO}

Earlier this year, oil spillage started in the Gulf of Mexico, causing environmental damage and death or harm to sea birds. Newspaper reports claim that the number of sea birds affected by the spillage stood at over 4,400. When the Exxon Valdez ran aground in Alaska in 1989, up to 250,000 birds were thought to have perished.

According to BP, it made its best efforts/endeavours to cap the spillage, but it failed to do so successfully. If and when the oil spillage could be completely stopped, the company would be required to clear the waters in the Gulf and bring them back to their normal state. The whole episode has been very damaging to BP. In addition to the cost of financial compensation, BP suffered a high profile casualty with the departure of its Chief Executive, Tony Hayward. BP's reputation as one of the largest corporate entities in the world has been tarnished; in London, environmentalists managed to have some of the BP's oil pumps closed at least for a day as a gesture in their protest against the company's perceived irresponsibility towards the sufferers of the disaster and the community at large. BP will be required to do more and spend even more money to regain its good image and prove that it is a socially responsible corporate entity after all.

\section{WHY ARE THE US AND PART OF THE INTERNATIONAL COMMUNITY SO ANGRY WITH BP?}

The economic loss for the sufferers of the disaster is enormous and far reaching. The blackened beaches in the Gulf of Mexico are a constant reminder of the alleged irresponsibility of BP in contributing to the disaster. BP and its agents may also be accused of gross negligence in dealing with the problem, and the shareholders also suffered a financial jolt.

In 2005, BP's refinery in Texas City caught fire, killing 15 workers and injuring more than 170 others. BP was fined and heavily criticised for numerous safety violations. In 2006, BP's pipelines in Prudhoe Bay, Alaska, were found to be corroded and leaking oil. Four years later, a repetition of a similar and larger incident was enough to push sufferers and sympathisers to the limit.

Curiously enough, it is common knowledge that BP is a company which believes in and maintains the principle of corporate social responsibility, and yet the Gulf of Mexico oil disaster required it to pay a huge price because it was construed by the disaster-stricken community and its sympathisers as a socially irresponsible act on the part of a corporate entity which earns staggering amounts of profits.

But the current disaster had a political twist too. The Gulf of Mexico oil spill received the highest attention of the US media. President Obama was determined not to stand accused of any indifference or negligence as his predecessor had been when Hurricane Katrina caused a 
disaster in the same area; the episode was politicised by the president's office when the president's personal popularity was at a low ebb in view of the current unemployment level in the US, although he should be commended for his performance in regard to many US issues.

During the immediate past, that is before Mr Hayward took over as Chief Executive, there was a perception that $\mathrm{BP}$ was very concerned with giving greater returns to its shareholders - even, some claimed, by compromising on safety (corporate social responsibility?). Mr Hayward also pursued a policy of greater satisfaction for BP's investors (a perfect gesture of corporate responsibility). Perhaps a different kind of corporate leadership was necessary which would combine profits with safety and reliable technological operation. The business of BP is "riskprone" rather than "risk-free." These risks were foreseeable.

\section{WAS BP LEGALLY LIABLE TO PAY THE VICTIMS OF THE DISASTER?}

It must be pointed out at the outset that $\mathrm{BP}$ did not have any contractual relationship with the victims of the disaster; in other words, there was no privity between the two parties. But what is the source of this obligation whereby $\mathrm{BP}$ agreed to pay compensation, and indeed did so?

There was no contractual obligation for BP to pay compensation, and the payment of compensation was based on two grounds: (a) a gesture of moral responsibility, the modern term of which is corporate social responsibility (BP, according to many, was in breach of this); and (b) BP's failure to correct the spillage promptly enough, which has been described as "negligence" on the part of BP.

Thus, to put it succinctly, although BP made its best efforts/ endeavours to cap the sources of spillage, the extent of damage caused to the local community and the need to protect its image decided the company to pay compensation. Two legal issues arise from this situation: (a) what was the nature of the negligence - deliberate or unforeseeable? (b) what efforts did BP make to minimise the cause of the disaster?

By paying compensation, BP admitted its liability in negligence, but the extent of the nature of negligence and the compensation should have been judicially determined, based on experts' opinions; otherwise, speculation would be the determining factor for calculating compensation.

The causal link between the oil spillage and the disaster entailing economic and environmental damage needs to be clearly established; it must be direct and not remote. The other issue remains whether the spillage was occasioned recklessly by $\mathrm{BP}$ - the circumstances of the case do not suggest so - when it happened. If the issue is raised of whether the perpetrator of the negligent act had a safety management system in place, and the answer is in the negative, then this will have a greater impact on liability.
However, even in the case of innocent negligence, reparation must be paid; thus, liability may not be avoided either way. Public emotion, which is not a legal criterion, should not form the basis for calculating compensation.

When a disaster on such a scale tales place, the accused is liable to pay not only the victims but also contribute towards the environmental damage caused by the act. Here, the ordinary principle of the law of negligence applies - do not harm your neighbours. Furthermore, under customary international law, environmental pollution and damage caused thereby are impermissible (see Trail Smelter Arbitration 1938- 1941, Annual Digest and Reports of Public International Law Case 1938-41, vol 9 at 315 , and subsequent international conventions on the Protection of the Environment; and see also the Rio Declaration of 1992). In BP's case, the adverse effect of oil spillage became so evident that it had no other choice but to accept liability. The economic losses sustained by the families and industries were enough to establish the causal link between the oil spillage and those losses. Human emotions ran high. The disaster became a national issue, and the Chief Executive of $\mathrm{BP}$ was required to appear before a US Congressional Committee.

Irrespective of the efforts made by BP to cap the source of the oil spillage, politicisation of the disaster and its consequential effect on the local communities necessitated a proper negotiation of the scheme of compensation. The extent of negligence on the part of the BP dominated the scenario; the issue of force majeure or unforeseeable circumstances leading to the disaster was relegated to a secondary position. BP became virtually defenceless.

What has never been disclosed to date was whether the oil spillage was caused by non-technological reasons, including the factors at the sea level which would overpower the protective/preventative capacity of the technology involved; in other words, whether the changing conditions at the bottom of the sea contributed to the disaster and if the technological device used, however sophisticated, could have withstood the rigour of those conditions.

\section{WHEN "BEST EFFORTS" OR "BEST ENDEAVOURS" WOULD NOT BE AN EXCUSE}

The term "effort" according to the Concise Oxford English Dictionary (2002) means "a rigorous or determined attempt." "Endeavour", on the other hand, stands for "earnest and industrious effort." An alternative meaning of "endeavour", according to the same source, is to exert oneself or to use effort or to attempt strenuously. Thus, from a legal standpoint, it would be difficult to maintain a distinction between "efforts" and "endeavours" or between "best efforts" and "best endeavours". Reasonable efforts or endeavours therefore imply only diminutive standards of "effort" or "endeavour". 
The terms "best efforts" or "best endeavours" tend to signify that a contributing party cannot be expected to perform or act beyond certain limits. Neither may be measured or quantified. One might argue that the quality of an effort or endeavour should be determined by reference to the relevant circumstances - but the fact remains that a degree of value judgment enters into the process of determining best efforts or best endeavours.

Contractual obligations are of an absolute nature; these may be not qualified by terms such as best efforts, best endeavours, reasonable efforts or reasonable endeavours. No compromise of contractual obligations is permissible. Furthermore, contractual obligations must be performed with diligence by each party to a contract. In the case of alleged negligence in performing contractual obligations, negligence must be established by referring to the principles of the law of negligence which entails "causality" - causal connection between the negligent act and the injury/damage caused to victims by it, in addition to satisfying the criterion of whether due care and skill have been exercised.

Interestingly enough, in Dahl v Nelson [1881] 6 AC 38 the court referred to the term "reasonable performance" but entered the caveat that what is reasonable must be determined having regard to the circumstances of the particular case. In Sheffield District Railway v Great Central Railway (1911) 27 TLR 451 the plaintiffs filed an action against the defendants alleging that the railway company, in breach of their obligations under the lease, failed to use their "best endeavours" to develop the through and local traffic of the Sheffield Railway. According to the court, the term "best endeavours" does not mean second-best endeavours.

In Terrell $v$ Mabic Todd \& Co (1952) 69 RPC 234 the defendants agreed to make their best endeavours to promote the sale of as many fountain pens made under certain designated letters patent as reasonably possible in certain countries, and to place the invention on the market and exploit it with all diligence. A similar contract was made by the defendant for promoting the sale of bottles of ink. The defendants failed to perform their contractual obligations and effectively repudiated the contracts, but defended their position by maintaining that their obligation was to use ordinary "business endeavours" and normal diligence.

“... the defendants' obligation was at least that of taking reasonable steps to exploit their inventions and design having regard both to the interests of their shareholders and their contractual obligations to the plaintiffs, that they had failed in this obligation" (at p 235).

In Terrell, business endeavours was equated with "reasonable steps" to exploit the inventions by the defendants, and even an undertaking to take reasonable steps was construed to be binding.
From a legal standpoint, it may be maintained that "best endeavours" stands for a lesser rather than an absolute obligation. A contractual obligation is absolute in nature, and that obligation cannot be compromised. Either there would be a breach of the contractual terms, or in order to avoid a breach the parties to the contract may prefer to renegotiate the terms of their contract, which act cannot be prevented under any legal system because the parties have agreed to do so.

Breach of contractual obligation(s) is one thing, but contractual negligence is another; the latter arises from negligence in performing the contractual obligations. But action on breach of contract or in negligence may be brought by the affected party to the contract - the principle of privity of contract.

According to Sheffield District Railway the term "best endeavours" means:

“... what the words say, they do not mean second-best endeavours ... they cannot be construed to mean that the Great Central must give half or any specific proportion of its trade to the Sheffield District. They do not mean that the Great Central must so conduct its business as to offend its traders and drive them to competing routes. They do not mean that the limits of reason must be overstepped with regard to the cost of the services; but short of these qualifications the words mean that the Great Central Company must, broadly speaking, leave no stone unturned to develop traffic on the Sheffield District line” (at p 452).

The court in this decision defined "best endeavours". What the court meant was that endeavours made by a defendant cannot be a "second-best"; "best" does not admit of any categorisation.

It is against such a dictum that $\mathrm{BP}$ or its agents will be required to establish that they made their best endeavours to seal the sources of leakage of oil in the Gulf of Mexico. But even then BP may not be able to avoid its liability under the principle of vicarious liability.

Walford v Miles [1992] 2 AC 128 was not directly concerned with the legal interpretation of the term "best endeavours" in a contract. Lord Ackner however incidentally explained the legal implication of the term when he stated, inter alia, that:

\footnotetext{
"The reason why an agreement to negotiate, like an agreement to agree, is unenforceable, is simply because it lacks the necessary certainty. The same does not apply to an agreement to use best endeavours" ( $p$ 38).
}

Little v Courage [1995] 70 P\&CR 469 was not directly concerned with the issue of exercising best endeavours by the defendant. However, in dealing with the case, Millett LJ, as he then was, explained the legal implication of the term when he stated that: 
"An undertaking to use one's best endeavours to obtain planning permission or an export licence is sufficiently certain and is capable of being enforced."

Incidentally, UBH (Mechanical Services) Ltd v Standard Life Assurance Co The Times, November 13, 1986, dealt with the issue of a tenant's covenant to use reasonable endeavours in the performance of the tenant's obligations under the lease. According to the court, the covenant to use reasonable endeavours was less onerous than one to use best endeavours.

John Mowlem v Eagle Star (1995) CILL 1047 was concerned with whether Mowlem's obligation to secure completion was merely an obligation to exercise its best endeavours to so complete. The Court of Appeal answered the question in the negative.

The gas sales agreement (GSA) in Phillips Petroleum Co UK Ltd \& Ors v Enron Europe Ltd [1997] CLC 329 contained the term "best endeavours or reasonable endeavours". Relying on Little v Courage, Colman, J said that:

“A provision requiring a party to use 'its best endeavours' to agree will in general be unenforceable, for that is just as

incapable of enforcement by reference to objective criteria as an agreement to agree."

On the basis of these decisions it is possible to conclude that the terms "best efforts" or "best endeavours" or "reasonable efforts or endeavours" may not exonerate a defendant from the burden of contractual obligations.

On the other hand, in Midland Land Reclamation Ltd and Leicestershire County Council v Warren Energy Ltd (1997) CILL 1222, Judge Bowsher stated that:

“To be satisfied of a breach of 'best endeavours' clause by one party or the other, I would wish to hear evidence that in the light of the knowledge available at the time of the alleged default the party alleged to be in default was culpable. In assessing culpability, I also take into account the unfriendly nature of the environment" (at p 1124).

This is what BP might rely upon; that the environment in the deep sea contributed to the disaster but that will need evidence to establish the absence of their culpability.

Recently, in CEP Holdings Ltd \& CEP Claddings v Steni AS [2009] EWHC 2447 (QB) the legal effect of "reasonable endeavours" was considered by the High Court. In this case the defendant served notice to terminate its exclusive distribution agreement with CEP on the grounds that CEP failed to comply with its express obligations under the agreement "to use all reasonable endeavours" to promote and sell certain products in the UK and Eire. According to the court, the parties must have understood the term "all reasonable endeavours" to mean that CEP and/or Claddings should have done everything that a reasonably competent distributor would have done to promote the sales of Steni's product in that territory. Based on the evidence, or the lack of it, to justify reasonable endeavours made by the claimants, the court found in favour of the defendant. Thus, in this case, the court maintained that the agreement "to use all reasonable endeavours" would be enforceable in the context of this case.

Whether "best efforts" or "best endeavours" have been made by the accused in correcting the cause of the disaster, it is to be emphasised that irrespective of any privity between the accused and the victims an obligation arises to protect the interests of the victims; and that obligation may be more onerous than the contractual obligation owing to the lack of care. Furthermore, when the adverse effect of all affects the interests, financial or otherwise, of those who are innocent and did not contribute to the negligent act.

In so far as a negligent act is concerned, the lack of foreseeability of the occurrence of the act if established by the accused would be enough to establish negligence. In the case of technology-based industries, the foreseeability of the failure of technology must be assumed. Thus there exists a continuing responsibility for "maintenance" of the technology. In the case of such industries, the lack of foreseeability of failure of technology may not be a defence. That the technology will perform in its best possible capacity in the circumstances / environment in which it is so intended to perform is also part of foreseeability.

If a disaster takes place despite satisfying the condition of "foreseeability" then the duty of the accused / perpetrator would be to minimise the consequences of the disaster properly and effectively. This obligation does not arise from any contract; it arises from the general notion that thou shalt not do any harm to anybody, a notion on which the law of negligence is based. In the Union Carbide case (1986) 25 ILM 771 the liability of Union Carbide was established not by directly relying on any rules of customary international law, but on the harm theory. When harm is caused, the accused must compensate the victims of the harm, and correct the harm promptly and effectively. Whether these two functions were performed by the accused would be determined by reference to its acts to correct the harm caused. "Best endeavours" or "best efforts" made to correct it promptly and effectively, but not fully corrected, may not be an excuse.

Thus, in determining the breach of a best endeavour clause and the degree of culpability of the accused in regard to a negligent act, external factors, such as the "unfriendly nature of the environment," may have to be taken into account. As stated earlier, in dealing with BP's liability in negligence by not using best endeavours, it is important that the unfriendly nature of the environment at the bottom of the sea is taken into account.

\section{RESPONSIBILITY OF OIL POLLUTERS}

It is elementary that oil companies must not cause any environmental damage including the pollution of seas or any other water courses. The "polluter pays" principle has been incorporated into the Rio Declaration of 1992, 
principle 13 of which provides that:

"States shall develop national law regarding liability and compensation for the victims of pollution and other environmental damage. States shall also co-operate in an expeditious and more determined manner to develop further international law regarding liability and compensation for adverse effects of environmental damage caused by activities within their jurisdiction or control to areas beyond their jurisdiction."

The crucial words in this article are "compensation for adverse effects of environmental damage caused by activities within their jurisdiction." Environmental damage may be caused by state itself or another entity, local or foreign within its jurisdiction.

This responsibility is of an absolute nature. As stated earlier, this need not be a contractual responsibility. This is a responsibility erga ones. The act itself gives rise to responsibility towards the entire world. That pollution of the environment gives rise to international liability in torts was established in the Trail Smelter Arbitration. Principle 2 of the Rio Declaration provides that:

"States have in accordance with the Charter of the United Nations and the principles of international law, the sovereign right to exploit their own resources pursuant to their own environmental and development policies, and the responsibility to ensure that activities within their jurisdiction or control do not cause damage to the environment of other States or of areas beyond the limits of national jurisdiction."

\section{THE DIVIDING LINE BETWEEN CONTRACTUAL AND NON-CONTRACTUAL OBLIGATIONS}

The dividing line between contractual and noncontractual obligations is gradually vanishing. A tort action is generally perceived as an action for damages, but a claimant may seek damages for breach of a contractual obligation; the breach is often an outcome of negligence in performing the contractual obligations.

In bringing an action in negligence, no privity between the wrongdoer and the wronged need necessarily be established. The causation will do - the causal connection between the causation of the harm and its effect on the victim must be proved. It is possible that the same circumstances may give rise to both an action for a breach of contract and the other for an action in tort.

In Edward v Mallan [1908] 1 KB 1002 the court held that the existence of a contract for the provision of medical treatment did not preclude an action for breach of the implied duties of care and skill which must be construed as the foundation of the law of negligence.

There is no reason why this principle may not be applied to the Gulf of Mexico episode. Based on the decision in
Hedley Byrne v Heller [1963] 2 All ER 575 it may be maintained that professionals (BP's appointed experts in installing the oil extraction system) must appreciate that at common law, which system is also followed by the US, their potential legal responsibilities may be derived from the principle of both the law of contract and the law of torts. JEB Fasteners Ltd v Marks Bloom \& Co [1981] 3 All ER 289 held, inter alia, that despite making best endeavours, in performing contractual obligations if any additional liability arises, whether to a party to a contract or a third party akin to the contract, the defendant may not have any grounds for seeking relief. A contracting party or the management of a corporate entity must avoid liability by providing the excuse that in performing its contractual obligations, it followed acceptable commercial practice (Edwards v Mellan at p 1002). Performance of contractual obligations with due care and skill and without any negligence is an absolute obligation for a contracting party.

In Esso Petroleum v Mardon [1976] 2 All ER 5, Lord Denning said that:

"... in the case of a professional man, the duty to use reasonable care arises not only from contract, and is therefore actionable in tort as well."

The same judicial principle may also be applied to engineering contracts. Engineering and construction works can never the totally risk-free. Hence the need for continuing supervision of such projects (see the Bhopal case); otherwise, it would give rise to contractual negligence signifying that the appropriate standards of care and skill were not maintained in performing contractual obligations.

Engineers, contractors and sub-contractors owe a duty of care to those whom they serve. There thus exists a duty in contracts as well in torts, and there also exists dual or concurrent contract and tort duties (see Donoghue v Stevenson [1932] AC 562). Out of the same contract two types of cause of action may arise - see Sidway v Bethlem Royal Hospital Governors [1985] 1 All ER 143 and Gold Harringey Health Authority [1987] 2 All ER 888. In the field of engineering / construction contracts, no distinction can be made between the duty of care and skill owed by the contractor to the employer in contract and that in the tort of negligence Cassidy v Ministry of Health [1957] 1 All ER 574 and Esso Petroleum $v$ Mardon - save that in the case of contract this duty arises by reason of the terms implied by the law (Thake $v$ Maurice [1986] 1 All ER 497) and in the case of torts under a duty imposed by the law (Esso Petroleum at 5).

As to standards of care, it is expected that in discharging its duty of care, an entity must demonstrate a competent degree of skill (Eyre v Measday [1986] 1 All ER 488). "Skill” cannot be compared with the ordinary competence of the reasonable man; it is the result of aptitude developed by special training and experience. In other words, when undertaking work requiring special skills, professionals and professional entities are required not only to exercise reasonable care but also to satisfy the standards of 
proficiency that can be expected of persons of their profession (Gold v Harringey Health Authority [1987] 2 All ER 888; Wilsher v Essex AHA [1986] 3 All ER 801; Bolam v Friern Hospital Management Committee [1957] 2 All ER 118; Whitehouse v Jordan [1981] 1 All ER 267 and Maynard v West Midlands RHA [1985] 1 All ER 635).

In setting standards of care, the law of negligence disregards any subjective element; it defines negligence in an objective fashion. An error in engineering judgment, though made without any malice, may amount to negligence giving rise to the contractor's / management's liability if in reaching its judgment it failed to exercise the legally requisite level of skill (Whitehouse v Jordan [1981] 1 All ER 267).

By the same token, in designing an engineering component a professional person or entity is required to exercise due care and skill attached to a particular profession which may be more onerous than that which an ordinary individual is expected to exercise. The finished product must be fit for its intended purpose (Independent Broadcasting Authority $v$ EMI Electronics Ltd and BICC Construction Ltd [1980] 14 BLR 1).

In the event of a negligent act continuing, law would expect the perpetrator of the act to deal with it as promptly as possible. Herein lies the source of liability in the present case - whether BP took sufficiently prompt action to cap the source of spillage. If not, then the quantum of damages will increase.

Two questions arise in this context: (a) whether BP and/or its agent(s) was entirely negligent in capping the sources of oil spillage, or (b) whether there was a natural cause, such as an adverse condition at the bottom of the Gulf of Mexico, which contributed to it. This information has not been officially disclosed by BP. However, based on the discussion above, it may be maintained that unless there was evidence of contributory negligence, BP would not be able to rely on the excuse that it made its "best endeavours" or "best efforts" to deal with the cause of nuisance. The issue of nuisance and its impact on the local community / communities is considered in the next section of this article.

\section{THE SOCIO-LEGAL IMPACT OF NUISANCE CAUSED BY BP OR ITS AGENT(S)}

The tort of nuisance can be either public or private. Private nuisance is an unreasonable interference with a private right to and enjoyment of land; this may arise out of physical interference with property or a broader interference with the use and enjoyment of proprietary rights. Interference must be unreasonable in all the circumstances. In order to determine the nature and extent of interference the court would normally take into account factors such as the location and character of the land, the duration and the consequences of interference. nuisance; it usually takes place when an individual or a corporate entity causes a nuisance which endangers the property, health or comfort of the public generally or prevents the public from exercising their rights. In AttorneyGeneral v DYA Quarries [1957] 2 QB 169 Denning LJ, as he then was, stated inter alia (at pp 190-91) that:

"[A] public nuisance is a nuisance which is so widespread in its range or so indiscriminate in its effect that it would not be unreasonable to expect one person to take proceedings on his own responsibility to put a stop to it, but that it should be taken on the responsibility of the community at large."

In the case of public nuisance, no privity between the victims (the claimants) and the defendant is necessary; however, although generally actions in public nuisance are by the state, private individuals with locus standi can also bring such actions on behalf of the victims.

Under US law, in order to make a claim on the grounds of public nuisance, there must have taken place "an unreasonable interference with a right common to the general public" (Restatement (Second) of Torts 821 B(1) 834). Two criteria are required to be satisfied for a nuisance to be treated as a "public nuisance": (a) that the nuisance must have adversely affected safety, health, comfort or convenience of the public; and (b) that it has become continuing in nature or has produced permanent or long term effect which the defendant knew or had reasons to know that it would produce such an effect upon the public's rights.

The high cost required for capping the leakage would not be a defence for BP because the public interest argument will overpower the high cost argument. In this case, the claimants were not required to do anything to reduce the costs; they only suffered both from environmental and financial standpoints. In order to establish that the defendants could have substantially reduced the spillage of oil with the help of experts the claimants can rely on Connecticut et al v American Electric Power Company Inc et al (O4-CV-05669 - US District Court for Southern District of New York). In that case, it was also argued that, in general, the plaintiffs in all jurisdictions would not only suffer economic losses arising from damage to property and businesses but also that the defendant's act caused harm to public health and ecological harms, such as the loss of forest and fishery biodiversity. The court found against the defendants.

The classic case on this issue is the Bhopal Disaster case (Union Carbide, supra) in December 1984. A chemical plant owned and operated by Union Carbide India Limited was located in the city of Bhopal, the State of Madhya Pradest, India; but 50.9 per cent of its stock was owned by the defendant, Union Carbide Corporation, a New York company. On the night of the disaster, a lethal gas, methyl isocyanate, leaked from the plant in substantial quantities in consequence of which over 2,000 people died and over 200,000 suffered serious injuries. Livestock were killed, crops damaged and many businesses were interrupted. 
Although the case primarily related to the issue of forum non conveniens, it was revealed during the proceedings on at least three occasions that Union Carbide (US) employees conducted safety audits at the Bhopal plant; two accidents had occurred previously at the plant, in consequence of which many employees were injured. Union Carbide (US) also allegedly assigned a key engineer to serve as UCCR Bhopal project manager, and who "assumed responsibility for virtually every aspect of the detailing of the process design" (p 786). Apparently, only four visits were made by Union Carbide process design engineers (US) to Bhopal. Furthermore, Union Carbide decided to store certain chemicals in large quantities at the Bhopal plant whereas these should have been stored in small amounts for safety reasons. Union Carbide (US) was also accused of the lack of supervision of the plant in Bhopal - a case of corporate negligence, contractual or otherwise.

In a much older case already referred to, Trail Smelter Arbitration, the arbitration was concerned with the settlement of the claims arising out of damage done in the US to crops, pasture lands, trees and agriculture generally, and livestock as the result of sulphur dioxide fumes emitted from the smelting plant of the Consolidated Mining and Smelting plant at Trail in British Columbia. Damage arising from the dissolving of the sulphur fumes had considerably increased since 1906, and especially since 1925. By the treaty of 1909 an American-Canadian Joint Commission was set up, but the Commission's recommendations were not accepted by these two governments. The dispute was submitted to an arbitral tribunal, which was asked to answer four questions centred around the issue of whether the Trail Smelter was required to refrain from causing damage in the State of Washington in the future, and if so, to what extent. Furthermore, if the answer to the above question was in the affirmative, then what measures or regime should have been adopted and maintained by Trail Smelter, and what indemnity or compensation should the Trail Smelter have paid to the US Government?

BP's case is very similar to Trail Smelter's. The award of the tribunal was, in reality, concerned with the principle of state responsibility and nuisance. The tribunal found on the evidence that the existence of an injury had been proved. It then proceeded to ascertain the causes of the injury, and reached the conclusion that:

"... the gases emerging from the stacks of the Trail Smelter find their way in the upper air currents, and are carried by these currents in a fairly continuous stream down the valley so long as the prevailing wind at that level is in that direction" (p 317).

As to state responsibility for injury emanating from its territory (nuisance), the tribunal held that:

"... that under the principles of international law, as well as the law of the United States, no State has the right to use or permit the use of its territory in such a manner as to cause injury by fumes in or to the territory of another or the properties or persons therein, when the case is of serious consequence and the injury is established by clear and convincing evidence" (Decision No 2, AJIL 35 (1941) at 716).

"The Dominion of Canada is responsible in international law for the conduct of the Trail Smelter. Apart from the undertakings in the Convention, it is, therefore, the duty of the Government of the Dominion of Canada to see to it that this conduct should be in conformity with the obligation of the Dominion under international law as herein determined" (op cit at pp 716-17).

In the BP case, neither the State of Louisiana nor the Federal authorities contributed to the negligent act and nuisance; but it fell on the US government to arrange relief to its citizens and take action against the wrongdoer. In the Trail Smelter arbitration, the doctrine of imputability applied; the Canadian Government could not avoid its responsibility as the nuisance was caused from its territory. In the Corfu Channel case (UK v Albania, ICJ Reports, 1949) the court applied the same principle. In that case, the court found that Albania was responsible for damage caused to British warships owing to Albania's failure to warn the British authorities of the presence of mines in Albanian territorial waters. The International Court of Justice (ICJ) stated, inter alia, it is a general and well-recognised principle that:

"every State ... [has an] obligation not to allow knowingly its territory to be used for acts contrary to the rights of other States" (op cit, at 22)

In its advisory opinion on the Legality of the Threat or Use of the Nuclear Weapons (1996), the ICJ stated, inter alia, that:

"The existence of the general obligation of States to ensure that activities within their jurisdiction and control respect the environment of other States or of areas beyond national control is now part of the corpus of international law relating to the environment."

In the $\mathrm{BP}$ case, the issue of the derivative obligation of the state in which $\mathrm{BP}$ was registered was not raised, and if it were raised, based on Trail Smelter it may be maintained that the jurisdiction could have been held liable. BP responded to the allegations made by the US Government, and admitted its liability. It may be pointed out however that in determining liability in the Trail Smelter, the arbitral tribunal stated that:

"... this problem need not be solved here as the law followed in the United States in dealing with the quasi-sovereign rights of the States of the Union, in the matter of air pollution, whilst more definite, is in conformity with the general rules of international law" (op cit at 317).

Thus, even if there were a state-to-state litigation or state-to-transnational corporation dispute it would be governed by the general rules of international law. When an international declaration or convention forms part of the general corpus of international law, it is immaterial whether a defendant state is a party to it or not. 


\section{WAS BP IN BREACH OF ITS CORPORATE RESPONSIBILITY OR CORPORATE SOCIAL RESPONSIBILITY?}

The intention here is not to enter into the academic debate on these two concepts which has been continuing over the past 75 years or so, but to take a practical approach to the concepts. Many authors have published books and articles on the concept of corporate social responsibility, of which a limited few are mentioned here: Berle and Mears, The Modern Corporation and Private Property (1933); Goyder, The Responsible Company (1961); Wedderburn, "The social responsibilities of companies", (1982) 15 Melbourne University Law Review 1; Fogarty and Christie, Companies and Communities: Promoting Business Involvement in the Community (1990); and Parkinson, Corporate Power and Responsibility (1994). The concept of corporate social responsibility evokes emotion in the minds of many. But what is the extent of this responsibility, and what is its source? The concept is unclear, and is emotionally-loaded.

The concept advocates that corporations must not do anything through their activities whereby harm will be caused to individuals or societies at large. But, this should be part of corporate responsibility. When one refers to the "harm" theory, one enters the zone of legal responsibilities and obligations of actors in the business communities. The law of negligence combined with contractual negligence covers the so-called corporate social responsibility of corporate entities. If, on the other hand, one maintains that corporate entities have responsibilities towards societies and social institutions, whether in the form of financial donations or rendering aid and technical assistance in the form of transfer of knowledge, then one will encounter difficulties in identifying the legal bases for these responsibilities.

Profit-making corporate entities are first and foremost accountable to their shareholders - there cannot be any other arguments against that. The concept of "enlightened shareholders" should not be confused with corporate responsibility. Because of the primacy of their responsibility towards their shareholders, responsible governments keep them under control by making them subject to legislation covering consumer protection, protection of the environment, employment legislation etc so that they do not cause harm to any individual and/or societies at large. The concept of corporate social responsibility lacks any legal base - it is based on the aspirations of its advocates.

Was BP in breach of corporate responsibility or corporate social responsibility? BP was liable in breach of corporate responsibility - it was liable in negligence and contractual negligence, and whether it had social responsibility or not, under the law of negligence it was obliged to pay damages to the sufferers of the harm, economic or otherwise. Having realised the extent of its liability it presumably decided to pay damages rather than become entangled in any prolonged litigation. The issue remains on what bases were damages determined.
The cases discussed or referred to in this work - Trail Smelter, Nuclear Weapons, Union Carbide - signify that these accidents took place either through a lack of supervision by the corporate entities concerned or negligence on their part. The time has now come to extend the scope of responsibilities for corporate entities through even more legislation.

\section{CONCLUSIONS}

In common law jurisdictions, in particular, liabilities arising from corporate disasters can be dealt with by applying the principles of the law of negligence. In earlier cases however, on issues such as environmental pollution, international law provides guidance unless the corpus of customary international law has already identifiably emerged in certain cases. It should be noted however that the rules of international law cover the negligent acts of transnational corporations although they are not subjects of international law. In the case Concerning Barcelona Traction, Light and Powder Company Ltd (Belgium v Spain) (ICJ, 1970), the court stated that:

\section{"... there exist basic obligations to the individual community as a whole ... that can consequently be asserted by any State" (at pp 172-73).}

If $\mathrm{BP}$ was found to be exclusively negligent in supervising and servicing technology in the Gulf of Mexico, and delayed in correcting the instruments whereby a spill could have been stopped much earlier, then of course BP would be fully liable to pay compensation to the victims of their negligence and clean up the environment. A mutually agreed sum of compensation need not follow the standard formulae used for computing compensation:

- the actual financial loss based on direct evidence;

- the potential financial loss based on the actual financial loss;

- the total loss of business;

- the reduction of the value of land caused by the nuisance.

(The Trail Smelter case outlined the heads of damages in the case of trans-boundary environmental pollution).

The BP-Gulf of Mexico episode was one of many such episodes. Whether one believes in corporate social responsibility or corporate responsibility, the fact remains that a wrongdoer has an obligation to correct the wrong and place the victims in their original situation as soon as possible. In the case of disasters of an extensive nature, the defendant cannot rely on force majeure or accidental wrongdoing.

\section{Professor C Chatterjee}

LL M (Cambridge), LL M, Ph D (London); barrister

Anna Lefcovitch

LL M; solicitor, EC Harris LLP 